\title{
Why We Buy Books
}

\section{Daniel Bunyard}

Daniel Bunyard is a publishing director and Head of Non-fiction Publishing at Penguin Michael Joseph, a division of Penguin Random House. After starting his career in academic publishing, working on history and philosophy titles at Palgrave Macmillan, he worked successively for John Blake, Orion, and HarperCollins before moving to Penguin as a commissioning editor for commercial non-fiction.

dbunyard@penguinrandomhouse.co.uk

Publishing is often characterized by instinctive decision-making with little attempt to apply a scientific methodology to an obvious question: why does one book sell and another not? The thesis of this paper is that, although there are aspects of a book's publication history that one cannot predict in advance, one can know what these aspects are. A simple syllogism underlies the argument: if human behaviour can be understood through psychology and if book-buying is a form of behaviour, the motivations for book-buying can also be understood through psychology. This approach can be applied historically, through recourse to sales data, to trace the fossils of books published long ago and so discover the type and strength of the motivations that once drove people to buy them. History demonstrates that these motivations, once properly framed, can be understood to be influenced by context. Book-buying motivations also appear cyclically. This leads to a discussion of why it is that one book rather than another may satisfy a motivation and therefore sell better than another. Using the concept of prisms combining to reflect a motivational 'light', we see that books exist as constructs of a finite range of elements that cohere (or not) in a multiplicative way to enhance or diminish their effectiveness. Evidence is also given for what appears to be a universal ratio that dictates a natural entropy in the effectiveness of these prismatic elements.

Keywords: publishing, cycles, big data, memoirs, celebrity autobiographies, motivations, book-buying trends, bestsellers, media theory, self-determination theory, SDT

\section{Introduction}

'What's the opposite of Brexit?' Although this might sound like the start of a joke, it was a question that my team and I asked 
ourselves repeatedly over the course of 2019. If Brexit, Trump, and the general state of the world made people feel anxious, divided, unsure about the meaning of life and the future, disconnected, pessimistic about human nature, and uncertain ... then what was the antidote, in book form? Why ask this question? Because, as one of the heads of commercial non-fiction publishing at the world's largest trade publisher, I have tried to find books that will sell lots of copies. I believe there are reasons why a book sells. In what follows, I have outlined three components that I believe are central: contexts, cycles, and the manipulation of what I call 'prismatic elements'.

At the outset, it is worth setting some parameters. There is so much one simply cannot know about a reader's individual response to a book, or about their motivations, just as it is impossible to predict the future and how it might influence a book's performance. Intuition and luck are part of the process of publishing for this reason. However, one can begin the search for what solid and universal truths might exist by stripping things back to their most basic. All sales of all books can be viewed as a product of two things: availability and desirability. The perception of availability (which a publisher influences through publicity, marketing, etc.) is as key as the reality of availability (enhanced through depth and breadth of retail exposure and reach into markets, variety of formats, etc.). The most desirable book imaginable will sell nothing if it is not available, both in a consumer's perception and in reality. Conversely, a book that is widely available and advertised to the point of saturation will sell nothing if it is undesirable. Lots has been written about the evolution of how books are made available: little has been written about what makes books desirable. This is despite the fact that proof of desirability is visible, through sales. Looking at historical sales creates opportunities to identify patterns. How frequently have books exploring the history of the Titanic, the Holocaust, or feng shui been published? How have they sold? Is there a peak historical volume? Is there a pattern to their frequency? Is there a historical contextual correlation with the sales pattern?

In the quest for patterns, it is possible to step beyond the arbitrary abstractions of genres into the realm of psychological motivations. For example, if one takes the top 10 bestselling titles of all time, as recorded by UK Bookscan, which promise that the reader will lose weight, the combined volume sits at around 7.5 million units. If one takes the top 10 bestselling titles that promise that the reader will live a longer life, the volume sits at around 150 ooo. If you asked someone on the street what was most important to them, living a long healthy life or being slim, you might anticipate that most people would opt for the former. Book sales say something different. Every book purchase represents a moment in time when a consumer felt that the transactional value of the book outweighed the money it would cost them. If a book was purchased it must by necessity have answered a motivation successfully. Downloading the entirety of UK Bookscan for non-fiction delivers around 400 ooo records for non-fiction alone, drilling down to titles that have sold just one copy. If you do this for fiction, or do the same for Australia, New Zealand, or any market you choose, you can begin to see evidence of something fundamental to publishing, from the past to the present and the future: the book market is universally driven by psychological motivations and the way in which they interact with historical context.

A range of observations and opportunities spring from this approach. Firstly, if it's possible to bring together groups of titles representing motivations rather than just genres, one can form a better understanding of how these motivations function within the markethow powerful they are, in relative terms, how frequent, and the peak historical volumes that have been achieved. This last point contains within it a potentially powerful tool for forecasting purposes: if one knows that the peak historical volume achieved for a book on vegetable gardening is $15^{2}$ ooo, that a new book on vegetable gardening typically sells over 10 ooo once every three years, then any sales estimation for a new book satisfying this motivation should lie between zero and 152000 and the frequency of sales over 10 ooo per annum should be a further point to consider in assessing risk and the probability of hitting that sales estimate. Secondly, it becomes possible to identify cyclical and contextual patterns not just for individual topics but also for motivations. Thirdly, there is now a possibility of developing a model of motivations which we can use to understand the patterns we see. 


\section{A theory of motivations}

Although Abraham Maslow's theory of motivations is perhaps the most widely known approach (Maslow, 1943), it has long been critiqued for a lack of empirical underpinning. In contemporary research on the psychology of motivations, the most comprehensive and widely accepted model is offered by 'self determination theory', developed by Edward Deci and Richard Ryan (2016). This distinguishes between deficit (or 'basic') needs and growth needs. The former, once satisfied, no longer preoccupy us. They fall into two camps: biogenic (including the need for sex, water, food, sleep/rest) and psychogenic (including self-esteem, security/certainty, and meaning/purpose). Growth needs, of which there are three-autonomy, relatedness, and competenceare never fully satisfied, since we are always capable of achieving a greater sense of them and will actively seek out opportunities to fulfil them. Above these exists the realm of instrumental motivations. These may be broad or highly specific, but they will inevitably correspond, to a greater or lesser extent, to the needs beneath them and, as such, are instrumental in satisfying them. Motivations to buy books are essentially instrumental.

Book-buying motivations themselves can be viewed as layered, since although they may be highly discriminated, it is possible to identify three underlying core motivations which echo and to some extent mirror the three growth needs. These three core motivations are: the hedonic motivation, the utilitarian motivation, and the motivation of self-identification. All books will, to

\section{These three core motivations are: the} hedonic motivation, the utilitarian motivation, and the motivation of self-identification.

some extent, satisfy one, two, or three of these motivations. Put very simply, the extent to which these motivations are both shared by a market and satisfied by a book dictates the extent to which a book sells. For example, you might ask: Am I buying this book for the emotional experience I think it will offer-for the thrill of forming a positive affective disposition towards a character and then witnessing their journey? Or am I buying a book for its utilitarian value - whether it's to learn how to grow vegetables, to lose weight, to live longer, or to learn something about the nature of existence, how people interact, how I might live my life. Or, finally, am I paying money for this book simply because ownership of the book will confer upon me a sense of positive selfidentification? As William James wrote, a 'man's self is the sum total of all that he can call his, not only his body and his psychic powers, but his clothes and his house' (189o, p. 279). James also suggested that one's yacht and horses made up part of who one was-less applicable these days, perhaps, but the point stands that the things that we can call 'ours' make 'us'. Likewise, books are often bought purely because they will enable the owner to feel a certain way about themself. This action can itself be seen as an expression of growth or deficit: I may select a book because I've decided that it will amplify my sense of self but I might equally buy a book because I fear that without it my sense of self will be compromised (how can I possibly consider myself to be plugged in if I haven't read that book that everyone's talking about?). Book purchases can be driven powerfully by just one of these core motivations or they can be driven by all three. Only a positive valence will drive sales (any book that requires the consumer to self-identify negatively will sell poorly, irrespective of its hedonic and utilitarian value), and the extent to which the motivation is satisfied will have a direct bearing on the volume of sales.

Enormous book sales can be achieved when one core motivation is unlocked by another. For example, the utilitarian motivation to learn the history of Western philosophy is surely a powerful one-who wouldn't want to absorb the thoughts of history's greatest thinkers, to be able to identify with them, on their level? - but it is a locked motivation, since one expects that it would be arduous and boring to access this. But what if it is clothed hedonically? If our intellectual journey is channelled vicariously through that of a child, so that we don't feel patronized? This is how Jostein Gaarder's 40-million-copy-selling 1991 novel Sophie's World functioned: it allowed the reader to tour the world of philosophy alongside a child protagonist. The book's use of the hedonic format of a novel made access possible to the utilitarian motivation. There are parallels here with 
works like A Pilgrim's Progress and the novels of Walter Scott. The former-published in 1678 , translated into over 100 languages, and a bestseller through to the 20 th century-packaged religion in an exciting, narrative manner, mixing religious allegory with the epic genre, in such a way that the utilitarian and self-identificatory (in that ownership implied piety) were clothed in the hedonic. Scott became a success at the start of the 19th century when popular culture experienced a broad historical turn. In the words of historian Donald Sassoon (2006), in reading Walter Scott 'one could learn about history surreptitiously while having fun, instead of ploughing through lengthy and tedious tomes written by professional historians and packed with burdensome facts'. Consider also how Defoe's Moll Flanders or the Marquis de Sade's La philosophie dans le boudoir both clothe themselves in supposed utilitarian value, flimsily masking the titillating hedonic value underneath. Defoe presented his book as a piece of earnest moralizing about the dangers of libidinous behaviour just as de Sade wrapped his scenes of group sex in cod philosophy. This outer layer was crucial to allow readers to selfidentify as students of morality or philosophy as opposed to being led by more prurient interests. Clothing the hedonic in the utilitarian enables a shift from negative to positive self-identification.

More recent examples can be found everywhere, for instance in economics. In the cases of Stephen J. Dubner and Steven Levitt's Freakonomics (2006, 621 ooo paperback sales) and Tim Harford's The Undercover Economist (2007, 217000 paperback sales) the combination is hedonic and utilitarian. Both books apply entertaining, anecdotal approaches to microeconomics, which, being concerned with the small scale, whether an individual or a business, is something we can imagine carrying potential application to our lives. Macroeconomics, by contrast, is beyond most people's realm of control and influence (we've never likely to be in a position to dictate rates of inflation). Can books on macroeconomics sell well? Of course, but one cannot assume the hedonic impulse will drive sales. Consider Thomas Picketty's Capital in the 21st Century (2014, 63 ooo hardback sales). It elicits the same process of blending core motivations, but this time the blend is utilitarian and self-identificatory. Such was the intellectual and cultural value attached to this book, the mere purchase and ownership of it conferred positive self-identificatory value upon the consumer. Its length and challenging contents were not a deterrentbut then neither were they for Marx's Capital, ownership of which has, through the years, been granted cultural, political, and intellectual self-identification, irrespective of whether the owner has made it past the first few pages.

We own objects to create, define, and understand ourselves, but we also gift them for similar reasons: the object we purchase and give is also a part of our 'extended self', to borrow cultural theorist Russell Belk's term (Belk, 1988, 2013), since we reflect ourselves in the selection of the object and hope for that self to be reflected back to us in the recipient's response. Gift-giving is therefore self-gratifying to the extent that the recipient positively supports the giver's extended sense of self. When looking at the motivation to self-identify through the purchase of a book, we must, then, take into account both the purchase of a book for oneself and the purchase of a book as a gift. Both motivations fall under the motivation of self-identification. Advertising legend David Ogilvy expressed this idea memorably: 'Give people a taste of Old Crow, and tell them it's Old Crow. Then give them another taste of Old Crow, but tell them it's Jack Daniel's. Ask them which they prefer. They'll think the two drinks are quite different. They are tasting images' (1983, p. 15). Our relationship with brands, images, and objects like books has such power that it can even supersede our basic human senses. A publisher's understanding, therefore, of whether a book represents a positive or negative opportunity for self-identification is critical. Books of huge hedonic or utilitarian value may never sell in serious volume if the consumer feels there is a risk of negative self-contamination.

Conversely, books of minimal hedonic or utilitarian value may sell copiously if a consumer feels they represent an opportunity for positive self-identification. It's worth considering how this pertains to other media. For example, many newspapers may have been sold in 2012 in the wake of the scandal involving Jimmy Savile, owing to people's fascination and disgust. Some agents and publishers assumed books about the scandal might sell well, but none did. Ownership of a newspaper is quite different from ownership of a book: one is, by definition, ephemeral; the other permanent. The sense, therefore, to which an individual may feel at risk of negative 
contamination is far greater if the content (even if identical) is housed in the form of a book, which will remain for ever part of you. Being seen reading a newspaper on a train is very different from a book being seen on the shelves of your home.

A mixture of the hedonic and utilitarian frequently crops up among history's greatest-selling titles, across both non-fiction and fiction. When the lasting appeal of high-quality writing is combined with a narrative that tells readers something universally and eternally true about life, then there is potential for long-lasting sales. Think of Cider with Rosie, Testament of Youth, The Diary of Anne Frank, My Family and Other Animals, or The Lord of the Flies, Of Mice and Men, The Life of Pi, The Kite Runner. All these titles share something in common (which they also share with Sophie's World): they feature child, child-like, or youthful protagonists, suggesting there is something key about the space between childhood and adulthood, when all of us learn lessons about the world and how to operate within it. Other examples might include Heidi, Anne of Green Gables, and the Harry Potter series, where the maturation of the central character is integral to the narrative. And a child's question of whether or not a book includes pictures goes to the very heart of the matter, since the inclusion of images injects hedonic appeal into what may seem dryly utilitarian.

When you look at historical sales data, it's no surprise to learn that the biggest area of adult non-fiction is memoir. Why? Because it is the best vehicle to satisfy not only growth needs, but also deficit needs for selfesteem and meaning. Memoirs satisfy needs for relatedness (we select an individual whom we relate to or aspire to feel relatedness to), autonomy (through the liberating sense of living someone else's experiences), and competence. One can establish a taxonomy of over a dozen facets of competence expressed in memoirs, whether it be achieving success through social mobility, overcoming grief, confronting mortality, etc. The extent to which books satisfy these needs is often directly reflected in sales.

Meanwhile, fiction is by its nature a vehicle to satisfy basic psychological needs. It is rewarding and satisfying insofar as it is successful in vicariously fulfilling the needs for autonomy, competence, and relatedness. Through the vehicle of a narrative and protagonist(s), we are freed to experience life from a variety of different perspectives (autonomy), to overcome seemingly insurmountable obstacles (competence), to ultimately achieve harmonious relationships with ourselves, with family, with idealized partners (relatedness). Fiction isn't mere escapism, mood management, or wish-fulfilment: fiction is psychological fulfilment through vicarious means. Again, the extent to which a piece of fiction is successful will be an indication of the extent to which the reader's psychological needs are satisfied. If Dickens and Tolstoy remain well read, it is because they still, to this day, enable readers to experience an exhilarating sense of autonomy through a range of characters and situations, competence through the experience of navigating complex, obstacle-beset narrative structures, and relatedness through intense identification with sympathetic protagonists.

Most successful films and novels typically build towards an apotheosis of satisfaction of one, two, or three of the basic psychological needs. Certain book genres are defined by this quality. For example, romance novels build towards an apotheosis of relatedness whereas the classic bildungsroman builds towards the protagonist achieving a sense of autonomy as an individual. A Lee Child or Clive Cussler novel will lead to an apotheosis of heroic competence. We choose narratives such as these with an expectation of that particular kind of apotheosis, but also with an expectation that the narrative will be replete with twists and turns, the evocation of upwards and downwards counterfactuals, which throw into jeopardy its resolution: Will Anastasia Steele and Christian Grey end up together? Will Dirk Pitt find the treasure and defeat the bad guy? Will Pip or Holden Caulfield arrive at a settled, true sense of themselves and the life they might lead?

This narrative trajectory towards a form of psychological resolution can be seen when Thelma and Louise finally express their autonomy by defiantly driving off a cliff, when Darcy and Elizabeth Bennett achieve a perfect state of relatedness through marriage; or through a combination of needs being met at once, as at the end of Return of the Jedi, the third and final film in the original Star Wars trilogy: Luke Skywalker finally achieves an apotheosis of competence as a Jedi warrior by facing Darth Vader, Darth Vader overcomes the tyrannical Emperor to save his son in a fatal apotheosis of personal 
autonomy, and the single thwarted love triangle of Luke, Han Solo, and Princess Leia resolves itself into a tripartite friendship, sibling relationship, and romantic relationship in an apotheosis of relatedness. The trilogy thus ends in an explosive, combinatorial satisfaction of the three psychological needs, which makes it immensely rewarding for the viewer. The epic genre, whether in film or in books, is often characterized by such a combinatorial effect.

Of course not all narratives end so happily. Thomas Hardy's novels typically end with an explosion of upwards counterfactuals that point towards what life could have been like: relationships consummated, fair recognition of competence, and freedom from societal constraints. This might seem to undermine the notion that narratives are successful to the extent that they satisfy psychological needs, but our relationships with narratives are complex and sometimes counter-intuitive: when a reader finishes a story loaded with needthwarting upward counterfactuals, they are left to return from the vicarious world of the text to the real world, with a sense of what they can achieve in reality - rather like waking from a bad dream with a sense of relief and optimism.

If the three basic psychological needs can be satisfied by both non-fiction and fiction, what of instrumental motivations? In the case of the former it is simple. For some readers, acquiring an ability to grow vegetables might be an instrumental method of satisfying needs for competence. Fiction, on the other hand, may seem more nebulous. Yet, if we can identify the salient extrinsic pressures on an individual and society at a given point in time, we can also identify ways in which fiction, for adults or children, offers intrinsically satisfying answers. You could say there are functional similarities between Paula Hawkins's Girl on a Train and the Netflix series Noddy the Toyland Detective insofar as both suggest ways for the consumer to navigate challenges specific to their age and situation. For a three-year-old making sense of the world around them, Noddy's attempt to navigate through Toyland, piecing together answers to questions like 'why?', 'where?', 'when?', 'what?', and 'how?', offers a vicarious dramatization of their own voyage of exploration, asking exactly the questions that most concern them at their stage of life. The motivation here, as with much children's entertainment, is both hedonic and utilitarian. As we progress through life the questions we ask ourselves evolve.

Although success on the scale of Hawkins's novel may be multi-causal, one can assert that it touched on two salient yet previously poorly articulated social concerns: 'gas-lighting' and casual, accidental middle-class alcoholism. Likewise Gail Honeyman's Eleanor Oliphant Is Completely Fine and the contemporaneous 'epidemic of loneliness' (Will, 2018). This is not to say that the presence of these themes and their working out through the narrative fully explain the books' appeal, but it is plausible that a large part of their buzz, their salience to an audience, derived from this. Crucially, fiction allows the reader to experience (and exorcise) emotions and issues vicariously. 'It's not me who's drinking too much/in a coercive relationship/feeling lonely/sexually frustrated, etc.; it's him/her; but I'm curious to see how this plays out, since I'll enjoy it and might even learn something from it ...'

To summarize: fiction and non-fiction can be seen as vehicles for the satisfaction of basic psychological needs. They achieve this through instrumental means. The three core motivations-hedonic, utilitarian, and selfidentificatory-found in books can be seen as instrumental motivations that serve to channel deeper drives and needs, primarily autonomy, competence, and relatedness. Yet, if book sales can be seen as instances of us satisfying our needs, how do these needs change over time-for both individuals and populations? Are there any patterns?

\section{The influence of context on motivations}

Although human psychology may not change, context does. However, if one looks at the recurrence of contextually similar periods across history, in terms of how the psychology of a population and market has been affected, one can see that people's responses to that contextshown through their interest in books-demonstrate parallels and echoes. In fact, the history of book consumption contains motivational echoes everywhere one looks: a 16th-century reader of Machiavelli's The Prince and an 18th-century reader of Lord Chesterfield's Letters to His Son may have experienced the same motivations and emotions as a 21st-century reader of Jordan Peterson's 12 Rules for Life or Ant Middleton's First Man In. All arguably fall into the genre of specula principum, or 
'mirrors for princes': a form of self-help book, typically aimed at ambitious yet unworldly young men. By the same token, if one were to trace the sales pattern of The Prince over four centuries, one would likely see an ebb and flow in correlation with periods when a greater proportion of readers felt a need for instruction, a sense of control, competence, self-esteem, and security. Sales of books of this kind during 2018 saw uplift that clearly reflected contextual changes. In the wake of 2017's Weinstein scandal and the \#MeToo movement, the market saw two clear developments: firstly, the rise of a wave of feminist literature (e.g. Elena Favilli and Francesca Cavallo's Goodnight Stories for Rebel Girls and Mary Beard's Women and Power) and, concomitantly, books that offered a market mainly of young men narratives presenting reassuringly strong and affirmative ideals of masculinity.

To take a step back to a more obvious starting point: book sales correlate with markets. Markets reflect populations and the statistical characteristics that define them (in terms of age, gender, etc.), but also fluctuating social, cultural, economic, and political environments. Motivations, as manifested in sales, are inextricable from their environment and indicative of what the population fears, loves, finds interesting, and so on. For example, in the UK, more wives buy books at Christmas than do husbands. An indicative ratio is found in the sales of Don'ts for Husbands and Don'ts for Wives (2007), as well as The Ladybird Book of the Husband and The Ladybird Book of the Wife (2015). The Ladybird Book of the Husband outsold the The Ladybird Book of the Wife by 12 per cent, while Don'ts for Husbands sold 354000 against 326 ooo for Don'ts for Wives, a difference of eight per cent. Secondly, what languages are Britons most interested in learning? Book sales would suggest French, Spanish, and German, since these three are by some way the highest-volume topics in the genre of bilingual dictionaries. This reflects the fact these are the top three most studied second languages in the UK. If one explored book sales in France, Russia, or any country with a sizeable market, one would see a correlation with that country's demographics; for example, sales of bilingual dictionaries would reflect the popularity of a different set of languages. If you take the 5000 bestselling titles in New Zealand over the last 20 years you find that 692 records feature the words 'New Zealand' and another 107 titles feature 'Kiwi': almost a fifth of the 5000 bestselling titles recorded by New Zealand Bookscan play upon the market's interest in and affection for their own country. In Australia, 254 of the top 5000 titles reference 'Australia' or 'Aussie' in some way, representing around five per cent. And in Britain? Eighty-four titles of the top 5000 reference 'English' or England, and 129 reference 'British' or 'Britain' - roughly 1.6 per cent and 2.6 per cent, respectively. Only three titles reference 'Scotland' or 'Scottish', and for 'Wales' and 'Welsh' there is not a single record. It is tempting to apply interpretations to this. The least controversial comment I can make is that each market expresses, to a varying degree, local interest (accepting that what may be locally relevant at a specific point in history is subject to change). For instance, UK Bookscan demonstrates that football memoirs massively outsell rugby memoirs, which in turn outsell cricketing memoirs. But the same does not apply in New Zealand, where rugby is by far and away the most popular sport. Thus, the motivations of a given market can to some extent be predicted through a closer understanding of its statistical characteristics.

Population trends and make-up are not, of course, sufficient by themselves to determine sales success. What matters to people at a given point in time evolves. History demonstrates that context supplies the extrinsic pressures and demands that activate the instrumental motivations manifested in book sales. Books like the Bible, Animal Farm, Lady Chatterley's Lover, and Wolf Hall are inseparable from context. They may have consistently profound resonance at a psychological level and ongoing contemporary relevance, but what initially prompted their salience is overwhelmingly likely to have had strong contextual grounds. The appeal and therefore sales of the Bible-rooted in salience-may wax and wane depending on context. The books of the Old Testament may once have provided direct solutions and answers to problems and questions of the time they were produced-the mystery of human origins, the necessity of legal stricture-but they also supply a sense of reassuring certainty more broadly, which might be more needed in some periods than others. For example, between 1952 and 1954, the Bible was the bestselling nonfiction title in the US (having never before in the 2oth century appeared in the top 10 bestselling titles of a year), and the fiction market simultaneously shifted 
towards titles with religious content: for example, The Robe and The Silver Chalice were the top two bestselling fiction titles in 1953. Why this religious shift in the early 1950s? Plausibly it was because, although the decade closed with a sense of optimism and prosperity, in the early 1950 s the US was experiencing economic uncertainty, shadowed by the threat of war, the atom bomb, army service, and the Doomsday Clock. Uncertainty acted as a complement to the Bible, a book that, for many, defines certainty.

It is well known that, in the wake of the First World War, there was an explosion of poetry, as if only poetry could express the horrors that had been experienced. In 1918, half of the top 10 bestselling books in America were poetry. Book sales during and after the Second World War show no evidence of the same trend. However, there is strong evidence for a similar explosion of interest in particular types of book. During the war, insider accounts-from within government, from the frontline, other countries such as Russia-held sway, then in 1945 there was an upsurge in cartoon books. That year, four of the bestselling books were cartoon compilations (Juliet Lowell, Dear Sir; Bill Mauldin, Up Front; Bennett Cerf, Try and Stop Me; James Thurber, The Thurber Carnival), along with two humour titles, including Betty MacDonald's The Egg and I.

By 1946, this mini wave had subsided and insider accounts returned to the fore. But, in the period immediately following the end of the war, an irrepressible explosion of joyful, celebratory humour dominated. We use poetry when ordinary words do not do justice to what we feel, just as cartoons offer a non-verbal outlet for humour. Both are also categories that don't usually dominate the bestseller lists. The same could be said of colouring-in books-in 2015 a sales explosion in this area arguably offered a compelling solution to the challenge of feeling calm in a modern, digital world-but we can go further on this point and reflect also that Sudoku puzzles in 2005, Magic Eye books in 1993, Scandinavian crime fiction in the late 2000s, and erotic romance in the early 2010 s all represented what previously were non-existent or small, relatively unpopulated areas of the market. There's a similarity between the observations of sales at the ends of the two wars-evidence of markets exhausted and saturated by with endless words written about the wars - and yet the mood and emotion reflected are strikingly different. If poetry captured a sense of loss and sorrow, cartoons captured elation and release. Note that cartoons are unlikely to have sold well during the war; likewise, in the three to four years after the war, there was a range of self-help books (Joshua L. Liebman's Peace of Mind and Dale Carnegie's How to Stop Worrying and Start Living) and historical books, such as Roger Butterfield's The American Past (or, in 1919, H. G. Wells's An Outline of History), that one cannot imagine selling in volume just a few years earlier. How could one justify one's interest in cartoons, self-help, or the historical past in a period that demanded selflessness and an engagement with the wider world? They would have carried negative self-identificatory qualities for the reader. Hence, each of these areas and the motivations corresponding with them were, in effect, suppressed throughout the Second World War, which perhaps contributed to their powerful resurgence after it.

As these examples demonstrate, one way to explore historical contextual influence is to see how particular areas of the market responded to periods of undeniable change. The 2008 credit crunch is an obvious recent example. In the area of money, economics, and personal finance there's very clear evidence of historical, contextual impact on sales in the UK. Before the financial crash, in each year from the mid-199os onwards we can see that the two or three leading titles focus on personal investment, peak yearly volume of any individual title oscillating between 60000 and 172 ooo. Then, in 2008, the peak volume of any individual title drops noticeably - to below 40 0oo-and the theme of 'investment' has entirely disappeared. The following year, we see 72 ooo copies sold of a book called Economy Gastronomy: Eat better and spend less. In 2010, peak volume is just 12 00o. It's not until 2011 that sales in this area to start revive, The 4-Hour Work Week selling 120 ooo, followed by a new edition of Rich Dad, Poor Dad. In 2012, the sales are poor but the focus has once again returned to investment. The years from 2013 to 2017 are fallow, perhaps because sales have shifted online and many people are finding financial guidance for free on sites such as YouTube. In 2018, the peak volume was just 1986 .

There's a lot of information here to draw conclusions from. Firstly, it seems obvious that, as the economy crashed, people no longer felt safe investing their money. That motivation effectively disappeared from 
the book market and took a good few years to reappear. We then see a further contextual impact-this time technological-affecting sales, since the motivation has arguably found satisfaction in other media. A second genre that shows a similar pattern running in tandem is 'house and home', where before credit crunch the sales were typically dominated by titles on DIY and cleaning. And then suddenly in 2008 the bestselling title is The Thrift Book (27 000). n 2009, DIY makes a comeback, but at a lower volume; only in 2011 does it make a significant recover (with a peak volume for an individual title of 78 ooo).

To pursue the thesis of this paper, we also need to look beyond genre and ask what else was happening in 2008 and the surrounding years, across the UK book market, and how broader motivational trends were activated. Three observations: sales of nostalgia titles picked up (seeking reassurance from the past, and from those who lived in it, who were, almost inevitably, financially worse off), misery memoir sales began to dip (indicating that our interest in and sympathy for the plight of others is diminished when we and our families are ourselves struggling), and sales of celebrity memoirs hit an alltime high. This last feature may seem surprising. Why would we spend money on books by celebrities? But the same thing happened in a noticeable way in 2018 and again in 2019, when after a long period of decline the number of celebrity books selling in excess of 100000 copies increased. In a period of deep uncertainty, when the population distrusted politicians and the media, seemingly trustworthy celebrities-whether it was Julie Walters and Dawn French in 2008, Michelle Obama and Michael Caine in 2018, or Billy Connolly and Elton John in 2019-stand out as beacons of reassuring familiarity, trust, authority, offering some sort of leadership on how we should live. Figure 1 shows the number of memoirs selling over 100 ooo, year on year, from 2003 to 2019 .

Not all of these memoirs in 2018 and 2019 were by celebrities (nor were they in 2006-2009), but recall the broader point that all memoirs teach readers something about how to live. For me, as a publisher, looking at this graph is rather like looking at the Event Horizon Telescope's image of a black hole, caught for the first time in history in 2019. It fills me with wonder and I believe it tells us something fundamental about the publishing galaxy. What we are seeing here is the impact of large-scale influences on a book-buying population.

Although motivational trends can sweep across the world, driving book sales with them - as with colouringin books and the motivation to find calm-contextual influences also frequently manifest themselves in local ways. (Note that colouring-in books, like Sudoku or Magic Eye books, also have the benefit of not requiring translation.) One thus often sees the same motivation (e.g. to deal with uncertainty) carry varying local expressions that might not travel outside their immediate environment. For example, it is relatively rare that truly original genres spring up, creating an additional space in the market, but since 2011 the Japanese fiction market has seen the happen in the form of iya-mys. This is known as

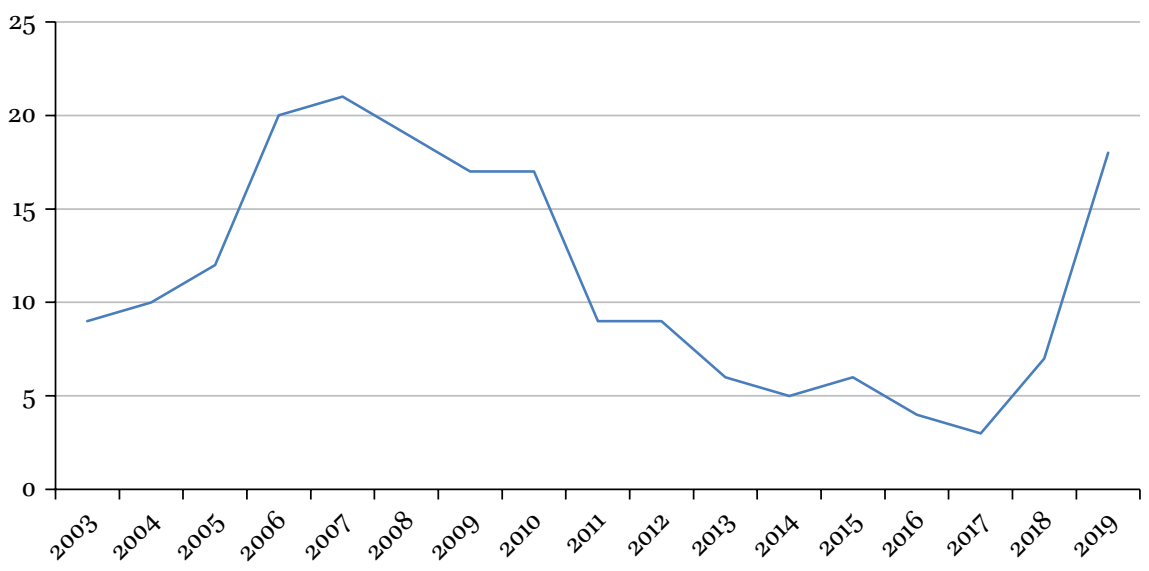

Figure 1. Number of autobiographies selling in excess of 100 ooo copies, 2003-2019. 
'unpleasant mystery' fiction. Novels in this genre are designed to make the reader feel a sense of distraught anxiety, intensifying their need for closure yet denying them it by leaving the narrative unfinished, unresolved. How can this be appealing? The answer is perhaps related to

\section{Novels in this genre are designed to make the reader feel a sense of distraught anxiety, intensifying their need for closure yet denying them it by leaving the narrative unfinished, unresolved. How can this be appealing?}

the concept of imaginal flooding - the idea that a bombardment of images of a certain kind produces desensitization to them (typically in relation to horror and violence). One can understand the trend through looking at the social context, as explained to me in 2019 by a Japanese agent: Japan's birth rate has been plummeting, the pension system is broken, and the economy is in perilous decline. Readers deliberately make themselves anxious to desensitize themselves to a world that feels uncertain, scary, and dangerously unresolved. But, critically, authors and publishers turn this into a form of entertainment by injecting hedonic appeal into narratives that perform this desensitizing function.

There is a parallel here across media formats, in the realm of deliberate desensitization, with the extraordinary success of the Netflix series Making a Murderer. Its appeal and buzz derive from sustained ambiguity and withheld closure. What other antidotes to uncertainty may exist in book form? There is a range: it could be through the reassurance of familiarity (see how the film market frequently revives and reinvents classics, from superhero movies to 1930 musicals); the reassurance of constancy and certainty (the market gravitates towards narratives offering a semblance of certainty and authority); the reassurance offered by desensitization, seen here through imaginal flooding (iya-mys); and the reassurance of catharsis. The last-mentioned is a possible reason for the contemporary explosion in popularity of psychological suspense narratives-where the plot, rather as in detective fiction, 'works as a disambiguating machine, which aims at restoring the univocity of signs, to reimpose a rigid causality in all things human' (Moretti, 1994). Whereas in detective fiction one looks for physical clues, in psychological suspense one searches for psychological clues, forcing the reader to harness and develop their theory of mind.

The examples above touch on macro trends and genres, but another piece of evidence that context influences motivations comes in the form of specific cultural touchstones or leitmotifs, often found across a handful of individual books. An international example from 2018-2019 is the pull towards remembering the Holocaust, through narratives retelling episodes from it, such as in Heather Morris's The Tattooist of Auschwitz and Edith Eger's The Choice. The rise of populism and the far right, across Europe and America, has arguably prompted a realization of the need to remember the severe dangers of what happens when fascism is taken to its logical extreme. We must learn from the past and books enable us to do so.

Whether or not people have been making this connection between past and present implicitly, it's possible to show that the influence on book sales is contextual by tracing back a little further to a period when there was similar alarm about increasing restrictions on civil liberties and increasing international aggression, and about a rise in fascistic ideology and terrorism: the period following 9/11, the onset of the Afghan and Iraq conflicts, and the London terrorist bombings of July 2005. Sales of John Boyne's The Boy in Striped Pyjamas achieved 29000 in hardback in 2006 and then 975 ooo in paperback over the following two years; meanhile, in 2005, Laurence Rees's Auschwitz sold 44000 in hardback and 173000 in paperback. Before then, Bookscan records show the highest-selling title relating to Auschwitz achieving sales of only 18 ooo. In 2011, Denis Avey's The Man Who Walked into Auschwitz sold 163 ooo in paperback; the paperback edition having been released in September that year, two months after the fascist terrorist Anders Behring Breivik killed 77 people in Norway. I would argue that the timing here was key and that the correlation between sales and environment - across three separate points over the last 20 years-is persuasive.

These few examples suggestively illustrate several points: that the strength of motivations, as represented 
by book sales, is partially dictated by the statistical characteristics of a market; that salient forces within culture, society, and economy often manifest themselves directly in the form of book sales; that the psychology of a given market will inevitably share parallels with other markets at different points in history-hence the fluctuating sales of books like The Prince, The Art of War, The Communist Manifesto, and the Bible as the historical context makes them more or less salient and useful.

\section{The cyclical nature of motivations}

Earlier, we touched on the point that certain motivations-as expressed through historical sales data-are inherently stronger than others. To take again the example of the promise that you will lose weight by buying a book, the combined total of the top 10 bestselling titles responding to that motivation have generated sales of 7.5 million over the period covered by Nielsen Bookscan. The peak volume is 1.23 million in paperback (Joe Wicks, Lean in 15, 2015), closely followed by two titles selling 1.1 million (Gillian McKeith, You Are What You Eat, 2004; Robert Atkins, Dr Atkins'New Diet Revolution, 2003). Diet books are known to be popular. But how regularly can one anticipate a bestseller, and how do such occurrences relate to the intensity of the motivation? In such areas, the occurrence of bestsellers can be too frequent for us to recognize the existence of a cycle (typically, one big breakout book occurs every $1-2$ years). With memoir the cycle is even more difficult to recognize: the wheel spins so fast that you can't make out the rate of revolution. But cycles do occur, everywhere, across non-fiction. The biggest areas, such as memoir, typically produce a number of big books each year, making it harder to identify cycles. If one takes a smaller area, such as puzzle/quiz books, the pattern is easier to see.

Figure 2 shows the number of puzzle/quiz titles selling 100 ooo or more, per year, between 1990 and 2018. Immediately, you will notice a bump, which corresponds to 2005's Sudoku craze, seeing 13 titles that sold over 100 ooo. Before that, there was a big hit with Who Wants to be a Millionaire? The Quiz Book in 1999 (422 ooo paperback). Going back further (when Bookscan records become less reliable), you can see evidence for a burst of successful titles in the early 1990s: a series of crossword books fronted by two newspapers, The Sun and Daily Telegraph. When we observe also the success of two puzzle books in 2016-2017 which sold over 100 ooo (The GCHQ Puzzle Book, 356 ooo paperback; Bletchley Park Brainteasers, 185 ooo paperback), it appears that there is a 6-10 year cycle. Before Sudoku, the cycle appeared to have a period of around six years. Following the Sudoku craze, the market (and motivation) perhaps needed longer to recharge, hence the longer, 10-year gap between Sudoku first breaking and the GCHQ (Government Communications Headquarters) puzzle book appearing. What does this tell us? We know that this is an area that can support big volume-peak volume is The Times Sudoku (729 000 paperback, 2005) - but also that such big-sellers do not occur every year. The average number of titles selling over 10 ooo copies each year, across the five years preceding the book's publication, was 1.4 for puzzles and 1.2 for quizzes. In other words, in any normal year, only two puzzle/quiz books will sell over 10 ooo. They're a tiny part of the overall market. But, every once in a while, the

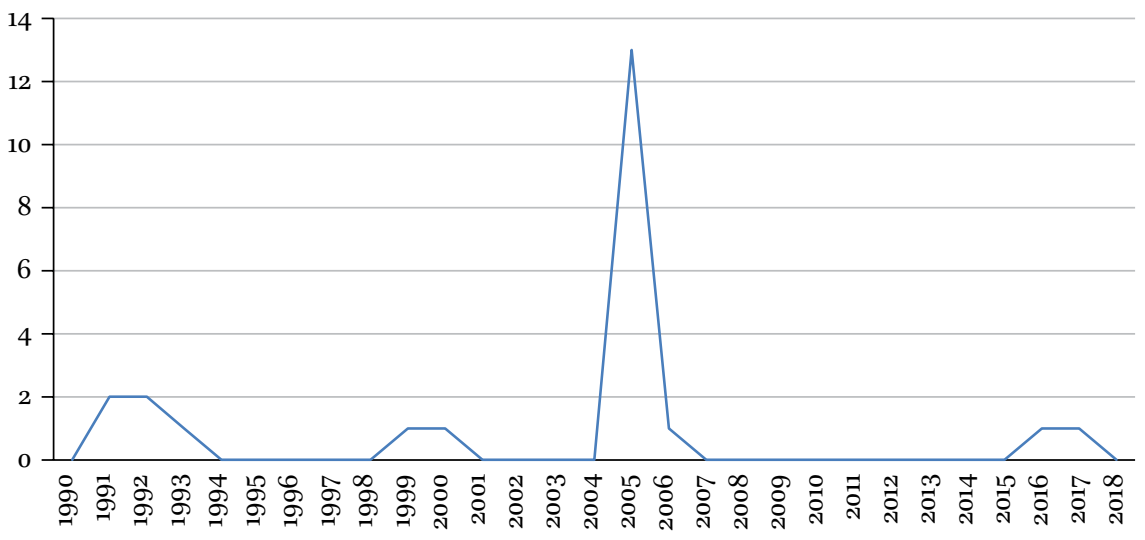

Figure 2. Number of puzzle books selling in excess of 100 ooo copies, 1990-2018. 
motivation (to be entertained by stimulating and challenging your brain) is sufficiently recharged for a bestseller to occur.

If you expand the search, you can see examples of similar cycles everywhere. Here are a few examples of motivations, along with the breakout books and the apparent cycles.

\section{Tidying your home (5-10-year cycle)}

1997 Lillian Too's Little Book of Feng Shui (232 000 paperback)

2003 How Clean Is Your House? (271 ooo hardback)

2014 The Life-Changing Magic of Tidying-up (198 000 hardback)

2019 Hinch Yourself Happy (490 ooo hardback)

Being entertained by cartoons / illustrated gift books (5-10-year cycle)

1998 The Simpsons Guide to Springfield (82 000 paperback)

2003 Bunny Suicides (182 ooo hardback)

2009 Simon's Cat (136 ooo hardback)

2015 The Ladybird parody series (more than two million copies)

2019 The Boy, the Mole, the Fox and the Horse (602 000 hardback)

Grammar / understanding how English works (5-10-year cycle)

1991 Mother Tongue (307 000 paperback)

2003 Eats, Shoots and Leaves (1.2 million)

2007 I before $E$ (218 ooo hardback)

2013 Gwynne's Grammar (42 000 hardback)

2018 Have You Eaten Grandma? (73 00o)

Film and TV tie-ins (four-year cycle)

1994 The Celestine Prophecy (391 ooo paperback)

1998 James Cameron's Titanic (187 ooo paperback)

2002 The Lord of the Rings: The two towers (126 000 hardback)

2005 Strictly Come Dancing (81 ooo hardback)

2011 The World of Downton Abbey (242 ooo hardback)
2016 The Making of Fantastic Beasts and Where to Find Them (86 ooo hardback)

Seeing the world from a different, beautiful perspective through art/coffee-table books (3-5-year cycle)

1995 The Story of Art (102 ooo paperback)

1997 The Art Book (203 ooo paperback)

2001 Earth from the Air (131 ooo hardback)

2006 Banksy, Wall and Piece (352 ooo paperback)

Be entertained by poetry (4-10-year cycle)

1996 The Nation's Favourite Poems $(465$ ooo paperback)

2002 Staying Alive Trilogy (132 ooo paperback)

2006 Surgically Enhanced by Pam Ayres (90 000 hardback)

2015 Milk and Honey (146 ooo paperback)

How to become more successful in life / self-development (3-10-year cycle)

1990 Power of Positive Thinking (70 ooo paperback)

1996 Emotional Intelligence (242 ooo paperback)

1999 The 7 Habits of Highly Successful People (443 000 paperback)

2004 Change Your Life in 7 Days (553 ooo paperback)

2012 The Chimp Paradox (431 ooo paperback)

Trivia (3-10-year cycle)

2002 Schott's Almanac (700 ooo hardback)

2005 Schott's Almanac 2006 (126 ooo hardback)

2006 QI Book of Ignorance (439 ooo hardback)

2012 QI 1,227 Facts to Blow Your Socks Off (159 000 hardback)

2013 QI 1,339 Facts to Make Your Jaw Drop (100 ooo hardback)

2016 QI 1,342 Facts to Leave You Flabbergasted (57 000 hardback)

What all this shows is that, rather like a volcano whose magma needs a certain amount of time to build up before it erupts, specific motivations for buying books seem to have a natural market tolerance. Once that 
motivation has been answered, in the form of a successful book, or sometimes books, the publisher needs to pause and wait until appetite has returned. The data tell us a great deal about the relative intensities of different motivations, but also demonstrate, as we'll see below, why it is frequently disastrous to place false confidence in the existence of an explosive trend, such as colouringin books. If an area has a 10-year cycle and a book appears that performs well but doesn't exceed the peak historical volume, the likelihood is that no more than one 'me too' book will perform well in its wake. The motivation will have been depleted.

Two mini-theories follow from this. Firstly, the notion that books sell on the basis of offering novelty and quality. Secondly, the observation that a universal ratio sits behind the entropy of book sales across series and sequences of titles. The first suggestion, that we want to know that something is new (at least to $u s$ ) and good (again, at least to $u s$ ) before we buy it, is hardly revelatory, but it is key to understanding cycles. Certain areas of the market demonstrate greater capacity than others for that thrill of finding something new. Memoirs, being the product of an individual's life, naturally tend to offer something new every time one is published (unless one experiences a whole sequence of 'me too' books, such as books by comedians, cricketers, etc.). Successful books on grammar, on the other hand, tend to need much larger gaps between them in order for them to feel new, because the content changes far less. Cycles exist in publishing not because there is some vast celestial wheel gradually revolving, influencing the market like the moon influences tides, but simply because the market responds to the sensation of novelty. The extent to which something feels new is linked to the sales volume of the titles that have preceded it as well as to the period of time between breakout books. If a book achieves massive volume in an area with a $5^{-10}$ year cycle, one will typically have to wait longer for the volcano to refill than one would if the sales were less impressive. The central reason for this is something we can call the 'universal ratio'.

In both fiction and non-fiction, a wealth of data show that if, across a series of books, the core elements and motivations attached to the books remain fundamentally unchanged, sales of each new title will typically achieve between 35 and 45 per cent of the volume of the preceding title. When the core elements and the core motivation remain static, sales operate under the influence of this ratio. The ratio plays out the same way, regardless of whether the pattern commences with a sales figure of 100000 (and then down to 40000,15 000, etc.) or at 450000 (and then down to 200000,80000 , etc.). This pattern can be seen to have played out often over many titles. The minute one becomes aware of it, evidence appears almost everywhere one looks. For an industry so often beset with status quo bias, it can be uncomfortable to face up to the reality of this pattern. We would love to believe that an author's next book will outsell their last, that our version of a book on hygge will outsell the previous one. Yet, even when we are supremely confident about the contents of a book (perhaps with good reason-maybe our book on hygge is better than the last one), the ratio none the less takes hold. Why does the ratio matter more than the contents? Because with each doubling of recurrence of a static prism and motivation, the market's sensation of novelty and quality is effectively halved (see Figure 3).

One fascinating aspect of this ratio's influence is that it also applies across groups of titles that are similar in their appeal to the consumer and yet have different authors. Consider two examples. Firstly, take The GCHQ Puzzle Book, which sold 354 ooo in paper back and was published in 2016. A sequel, The GCHQ Puzzle Book II, was published two years later and sold 90 ooo in paperback. Clearly, this doesn't match our universal ratio. But note that in 2017 , between these two titles, was published a book called Bletchley Park Brainteasers, which, although unconnected in any way with the government department GCHQ, was deliberately packaged and marketed in a very similar way, Bletchley Park having been the home of the GCHQ code-breakers during the Second World War. It attempted to employ the same blend of motivations and prismatic elements to achieve the same effect. It sold 184000 in paperback. Across the three titles, the tail-off averages 50 per cent from one title to the next. In other words, Bletchley Park Brainteasers functioned to the consumer as the second book in a series of three. Secondly, between 2018 and 2019, there was a wave of books featuring swarthy tough guys on their covers, beginning with Middleton's First Man In. We saw earlier that there may have been a contextual reason why a book like this performed so well (bearing in mind that 

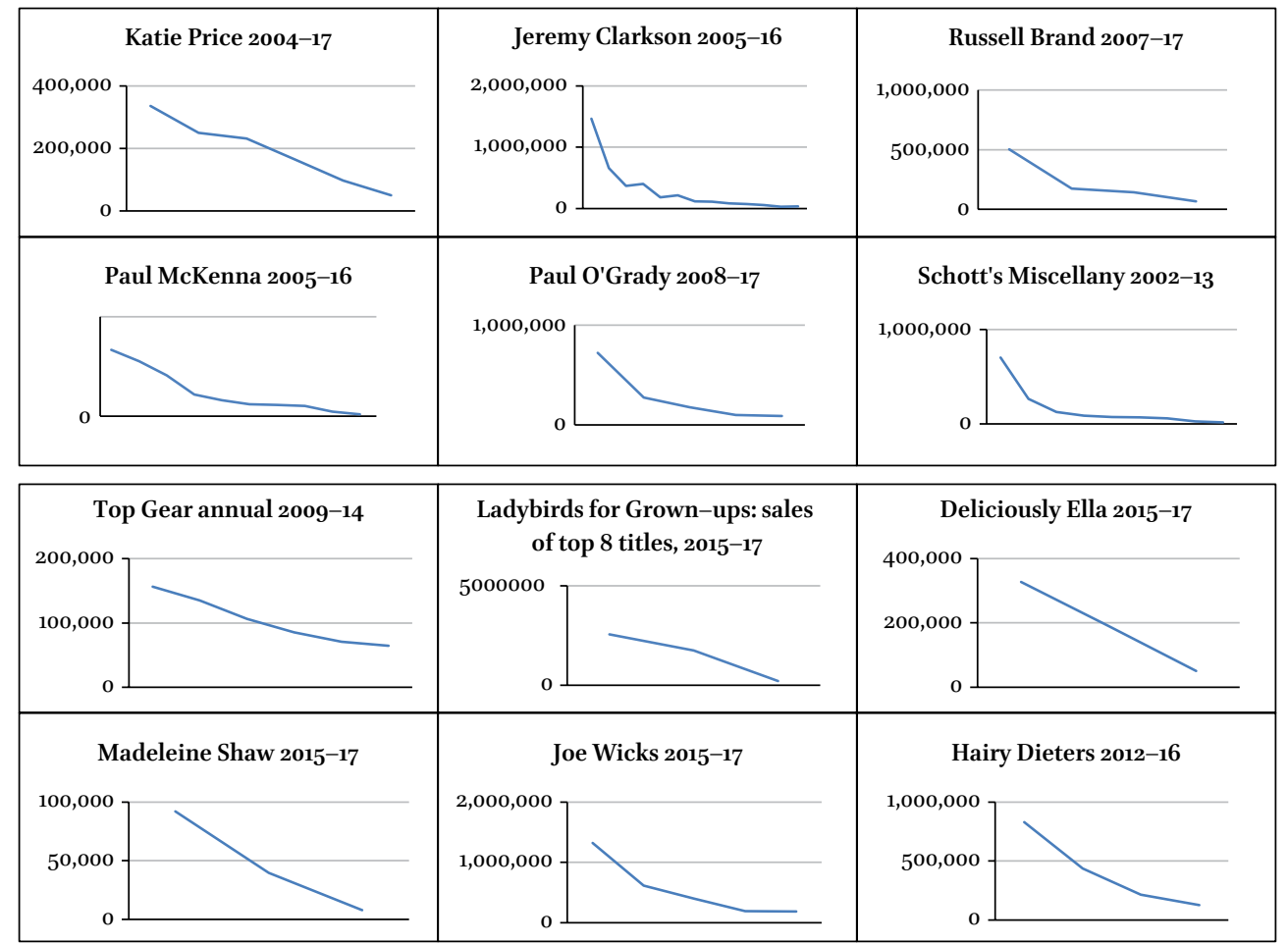

Figure 3. A range of examples demonstrating the 'universal ratio' in play.

one would never previously have anticipated that a memoir from the presenter of a Channel 4 TV show with unremarkable viewing figures would achieve remarkable sales figures). Three books by three different presenters from the same SAS: Who dares wins TV show follow the familiar trajectory:

\section{Ant Middleton 248 ooo 231 ooo 479 ooo in total hardback paperback \\ Jason Fox $\quad 127000 \quad 94000 \quad 221000$ in total hardback paperback \\ Ollie Ollerton 48 ooo 20 ooo 68 ooo in total hardback paperback}

From the first to the second book the sales declined to 46 per cent of the preceding volume. From the second to the third book, they declined to 30 per cent of the preceding volume.

There are reasons why this somewhat counterintuitive behaviour of the market is important. Firstly, it reflects the point that the market responds to the sensation of novelty. This can be more important than the sensation of quality. It does not actually matter if the second, third, and fourth books are qualitatively 'better books'. The market does not much care. It therefore does not matter if a publisher has paid an arm and a leg for the first author, the one who started the wave, and has promoted the book heavily: if the motivation that the first book represented has been depleted by books by authors 2,3 , and 4 then the publisher cannot expect to buck the influence of the universal ratio. This implies that the author and the content may sometimes matter far less to the market than does novelty or than the satisfaction of motivational needs which that author may have achieved. This observation leads to another-that it is the holistic effect of a book rather than its constituent components which is paramount: the examples above demonstrate that books can be viewed as constructs, the parts of which one can separate out, define, and analyse, and each of which may carry relative weighting and power at different points in time. Before resuming this line of argument, it's worth looking at what happens when cycles and context collide. 


\section{The combination of cycles and contexts}

When contextual and cyclical influences combine in a positive way, the results can be extraordinary. To give one example, which brings together both of the market tendencies we've been looking at: in 2019, Penguin Random House published its fastest-ever-selling nonfiction book, Hinch Yourself Happy by Instagram sensation Sophie Hinchcliffe. Pre-orders of 80 ooo copies sat behind an initial print run of over 200000 , and it has now sold in the region of 490 ooo. As we have seen, the topic of 'cleaning and tidying your home' was a dormant volcano; before the book's publication, there was both evidence of a $5^{-10-y e a r ~ c y c l e ~ a n d ~ a ~ g a p ~ o f ~ f i v e ~ y e a r s ~}$ since the last peak. Moreover, the contextual motivation to feel calm and in control was immensely powerful throughout 2018-2019, in the midst of uncertainty around Brexit. Cleaning and tidying your home offers the reader a way in which they can achieve calm and a sense of control over their immediate surroundings, even if the bigger environment feels out of one's control. In addition, a social context in which loneliness is on the rise means that anything offering the ability to connect with others, to join a tribe, is appealing. Sophie Hinchcliffe and the two authors behind the slimming brand A Pinch of Nom denote just this: a chance to join a club, providing the reader with a strong feeling of relatedness. Hinch Yourself Happy demonstrates a powerful simultaneous conjunction of cyclical and contextual motivations.

That cleaning and tidying is an area that will, thanks to cyclical and contextual influences, produce breakout successes can be seen in a publishing phenomenon from a quite different time and place: that of 'Heloise', or Ponce Kiah Marchelle Heloise Cruse Evans. She and her mother produced a popular local and then national newspaper column called 'Hints from Heloise'. In the early 196os, it became syndicated across 600 US newspapers. A series of books followed, the first of which, Heloise's Housekeeping Hints, sold over half a million copies in hardback in 1962. As Hinch Yourself Happy arguably benefited from the context of uncertainty surrounding Brexit, it is worth asking what else was going on that might have provided a contextual reason for the success of Heloise among the US readership of that time, something that may have created similar feelings of uncertainty, stress, and being out of control? The answer: the Cuban Missile Crisis of October 1962. It's interesting to note the striking similarities of the cover design of the original Heloise paperback to a press photoshoot undertaken by Sophie Hinchcliffe (Figure 4). Across a gap of 60 years, two different markets
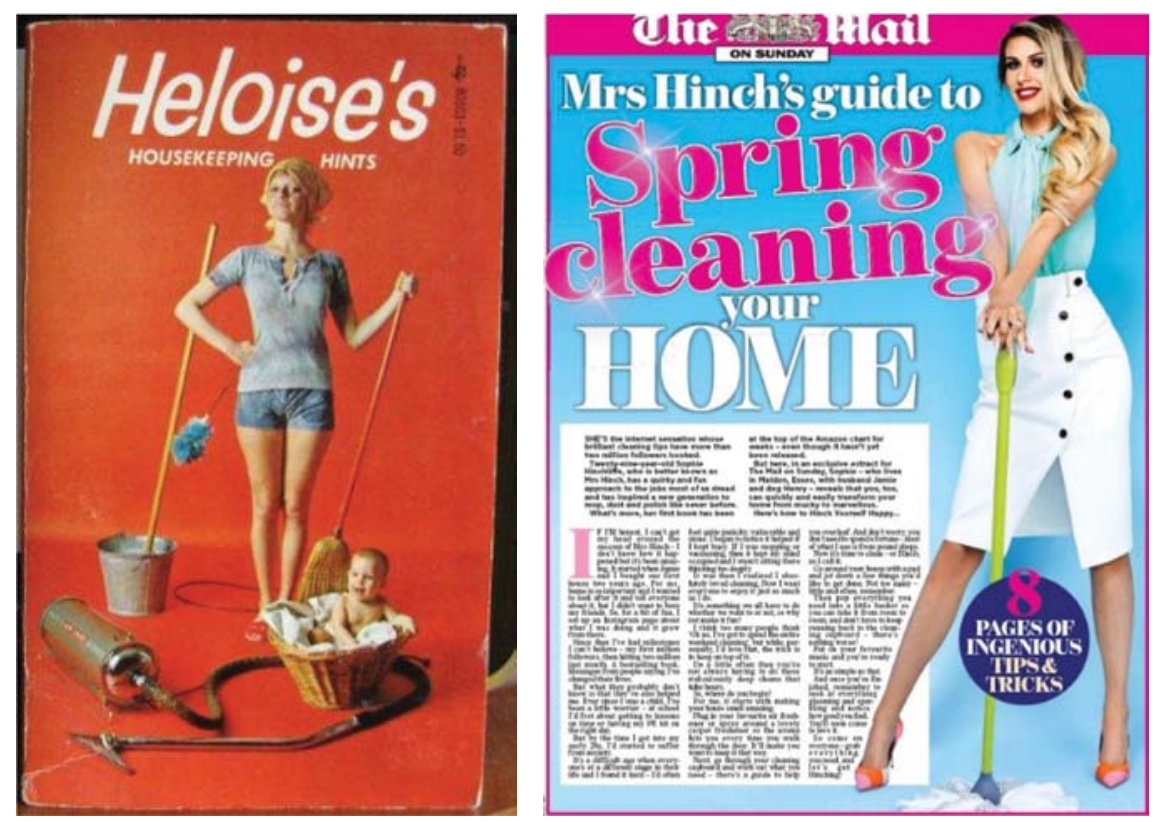

Figure 4. The front cover of 1963's Heloise's Housekeeping Hints and publicity promoting 2019's Hinch Yourself Happy. 
responded in startlingly similar ways to psychologically similar contextual stimuli.

If Hinch Yourself Happy helped consumers to feel in control of their domestic sphere, gave them a sense of competence, positive involvement in a community, and relatedness, were there other books in 2019 that satisfied these needs? If Britain in 2019 felt divided, hopeless, frustrated, unsure of its direction, lacking in meaning and optimism, despairing of climate change, Trump, etc., a book might have been expected to perform well if it expressed uncomplicated and childlike hope, positivity, themes of friendship, love, unity, and support, and a sense of uplifting warmth. Even better if that book could appeal to children and adults, women and men, so that its core messages of social competence and relatedness could be more easily shared-thus giving the giver as well as the receiver of the book a positive feeling of selfidentification. The Boy, the Mole, the Fox and the Horse by illustrator Charlie Mackesy did just this. Contextually, it landed on fertile ground. Critically, as noted above, it fell directly into a cycle that already existed, for illustrated gift books. It has sold 601000 copies, and rising.

These things are predictable. Or rather, it is predictable that a book that meets certain criteria will perform well. Contexts and cycles are aspects of book markets. Knowing how they work may not ensure that a publisher picks the specific title that will activate a dormant volcano: as we have seen, often only one book will benefit from the moment in time that a cycle offers. Yet to activate a cycle should be a consistent goal of any commercial publisher, difficult as it may be. Meanwhile, understanding the influence of context provides even greater opportunity: if a temporary or ongoing deficit need is displayed within the market — for calm, meaning, relatedness, or anything else-it follows that the market will respond to any book that offers a new and good response to it. Markets may favour originality when it comes to individual books, but what they want fundamentally, in terms of the motivations it satisfies, is as old as civilization. As advertiser Bill Bernbach (1911-1982) expressed it:

Human nature hasn't changed for a billion years. It won't even vary in the next billion years. Only the superficial things have changed. It is fashionable to talk about changing man. A communicator must be concerned with unchanging man-what compulsions drive him, what instincts dominate his every action, even though his language too often camouflages what really motivates him. For if you know these things about a man, you can touch him at the core of his being. One thing is unchangingly sure. The creative man with an insight into human nature, with the artistry to touch and move people, will succeed. Without them he will fail. (Quoted in Ogilvy, 1983)

To recap, we've seen that motivations and the sales of books are subject to contextual and cyclical influences; that there is a hidden ratio dominating sales patterns. But how can one then explain the third, fifth, or seventh book in a series which suddenly changes everything, or sales patterns that show massive fluctuation? Understanding of cycles and context may help us look in the right direction for the next bestseller, but it cannot find it for us. What is it that makes one book succeed and another fail?

\section{Prisms}

In trying to work through the conundrum of why one book sells and another does not, a metaphor may be helpful. If book sales on a large scale are driven by market motivations, such motivations can be thought of as so many beams of light, carrying relative degrees of brightness and intensity. Individual books are effective at satisfying these motivations if the combination and integrity of their constituent parts are successfulhence one can think of books as prisms, or a combination of prismatic elements, blocking, diverting, recomposing, or brightening that light. We can therefore build a better understanding of how these combinations work by playing around with additions and subtractions. Would Carlo Rovelli's Seven Brief Lessons in Physics have sold so well if it were simply called Lessons in Physics and if it were 500 pages in length rather than the short, small book it is? If not, why not?

As a starting point, it makes sense to list the full range of things that one might consider to be prismatic elements. Some are fairly obvious: title, author, recommended retail price (RRP), format, cover design (which may reflect a combination of elements). Others may be conferred by success: prizes, endorsements, bestsellerdom. But there is also a conceptual realm to considerwhat you could call the 'vehicle' by which content is 
Table 1. A range of hypothetical prismatic elements

\begin{tabular}{|c|c|c|c|c|}
\hline Author & Subject 1 & Subject 2 & Title & Vehicle \\
\hline Ian McKellen & Shame & Evolution & Wit and Wisdom of $X X X$ & Poetry \\
\hline Jeremy Paxman & Male mental health & Darwin & Atlas of Remote $X X X$ & Phrase book \\
\hline Richard Shepherd & Grief & Body confidence & $X X X X$ Last $X X X X$ & $\begin{array}{l}\text { Costumed guinea pigs/ } \\
\text { hamsters }\end{array}$ \\
\hline Kathy Burke & Feminism & Agatha Christie & $\begin{array}{l}\text { Person's } X X X \text { (e.g. Stalin's } \\
\text { Englishman })\end{array}$ & Colouring-in book \\
\hline Lauren Laverne & The English Channel & Wellington & $X X X X$ Lost $X X X X$ & Where's ...? \\
\hline Kirsty Young & Grammar & Lady Diana & The Meaning of $X X X$ & Exploration of subject \\
\hline Laura Kuenssberg & Jokes & Elizabeth I & Meditations in a Time of $X X X$ & Bilingual dictionary \\
\hline Boris Johnson & Maths & The Mitfords & The Young XXX & $\begin{array}{l}\text { Book plus object (e.g. } \\
\text { tarot deck) }\end{array}$ \\
\hline Emma Thompson & Britishness & Queen Victoria & The Last XXX & Graphic novel \\
\hline Idris Elba & History & Parliament & The Little Book of XXX & Aphorisms \\
\hline Gyles Brandreth & Englishness & Henry VIII & The Art of $X X X$ & Spoof memoir \\
\hline Stephen Fry & Manners & Stalin & The NUMBER of $X X X X$ & Spoof artefact \\
\hline Sandi Toksvig & Trees & Jesus & A Brief Guide to $X X X$ & Memoir \\
\hline Sue Perkins & Cats & Charles Dickens & The Museum of $X X X$ & Counter-factual \\
\hline Richard E. Grant & Dogs & Jane Austen & The Secret $X X X$ & Visual treasure hunt \\
\hline Helen Fielding & Electricity & Mozart, Beethoven, etc. & The XXX Effect & Miscellany of ... \\
\hline Imelda Staunton & Coal & Mini & The Life-Changing $X X X X$ & Puzzles \\
\hline Alison Steadman & Horology & Beetle & The Pianist/etc. of $X X X X X$ & Quiz \\
\hline James Corden & Oscar Wilde & Tractors & A Short History of $X X X$ & Biography of individual \\
\hline Julie Walters & Shakespeare & Big Ben & $\begin{array}{l}\text { Play on words which indicates } \\
\text { subject }\end{array}$ & Biography of location \\
\hline Rupert Everett & Churchill & Everest & Why We XXX & Biography of object \\
\hline Henry Hemming & Einstein & Gestapo double agent & XXX Intelligence & $\begin{array}{l}\text { Choose your own } \\
\text { adventure }\end{array}$ \\
\hline William Hague & Climate change & Cold War double agent & Conversations with $X X X$ & Cartoons \\
\hline
\end{tabular}

relayed - and the content itself: the combination of subjects covered.

Table 1 shows a series of core prismatic elements arranged in columns. One could populate a table like this with an infinite range of titles, authors, and subjects, and of course the ways in which these could combine are also potentially infinite. Arranging the elements in this way offers a simple way to understand how the elements combine together as well as to demonstrate the wealth of opportunity for an author, agent, or publisher. Books can emerge, conceptually and literally, from a table like this: highlighted in dark grey is Boris Johnson's The 
Churchill Effect, whilst highlighted in pale grey is Gyles Brandreth's Have You Eaten Grandma? The question for a publisher then becomes, "What combination of elements works most effectively, and why?' Before we attempt to answer that, it's worth noting that in this discussion of prismatic elements we have not yet used the word 'contents'.

\section{A brief word about content}

The position taken here, which may seem controversial, is that the contents of any book simply need to be good enough. We are not asking the question, 'What makes a book any good?' but rather, 'Why do people buy books?' They are very different questions. The theory of prisms and motivations gives us a way to understand why and how the expectancy value attached to any book is created and developed. It is expectancy value that leads to a book purchase. This value can sit outside any consideration of the contents of the book and is only jeopardized if the contents are not good enough, that is, if the experienced value does not match the expectancy value. In other words, it is the expectancy value that determines a book's sales, so long as the experienced value is not markedly discrepant (see Figure 5).

There are only three outcomes here: a book fails to meet, meets, or exceeds its expectancy value. If the experienced value is consistently higher than the expectancy value, then word-of-mouth recommendation will undoubtedly grow, gradually increasing the book's expectancy value as part of an ongoing feedback loop.
Thus I'm not saying that content doesn't matter-it is central to the intensity with which motivation is satisfied. But our understanding of content is flawed. Our belief that 'content is king' is so ubiquitous and engrained that we rarely question it. Michael Bhaskar (2013) says, "There is no such thing as content-free publishing ... The idea is nonsensical.' However, consider a book published in 2013 entitled Everything I Know about Teaching by Michael Gove (a joke book-he didn't actually author it) which simply consisted of blank pages and which sold 11000 in paperback. This is not a huge sales figure, but bear in mind that it was a book utterly devoid of content. The only value it carried was an expectancy value based around its potential as a gift (for a disgruntled teacher, probably); the only experienced value it had was in the moment of receiving it and comprehending the joke. (This is not a new vehicle: a possible prototype was the 1977 book All That Men Know About Women.)

This may seem a fatuous example, but the point is worth considering: think how Stephen Hawking's $A$ Brief History of Time, which has sold over 10 million copies, became a book that infamously was much bought but little read. Its title promises simplicity yet also the broadest, most profound, and valuable of content: an understanding of the universe. It also happened to be a difficult book to read. But the expectancy value it carried and still carries is enormous even if the experienced value is minimal-composed, for most readers, of frustration and a sense of incompetence, yet conjoined with positive

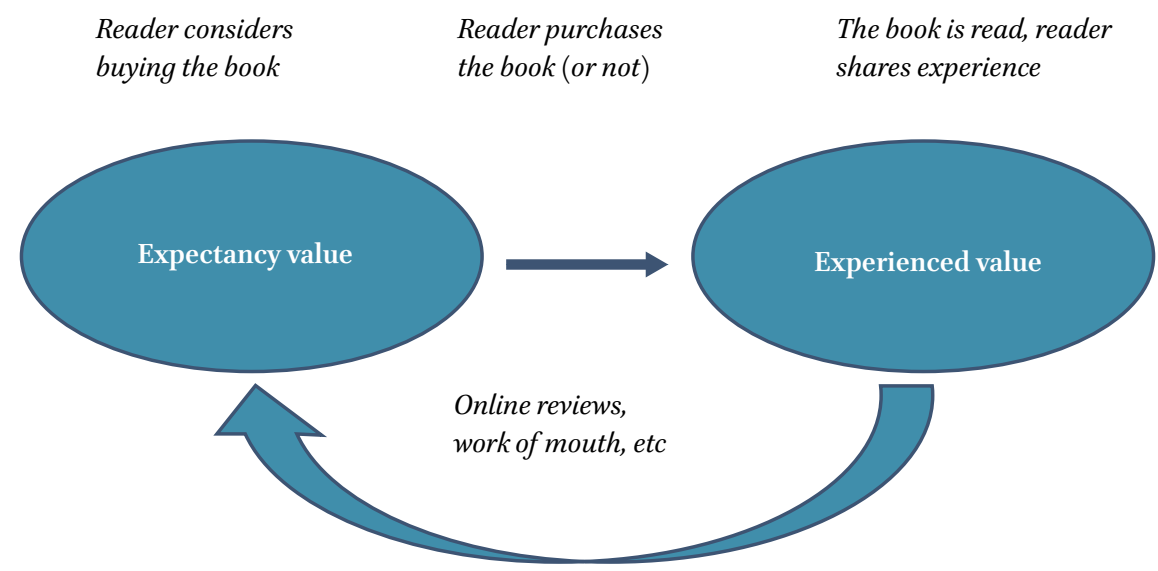

Figure 5. The feedback loop between expectancy value and experienced value. 
self-identification: 'It's on my bookshelf, I'm clearly smart enough to own it, and I'll read it at a later date...' In this example, it's worth pointing out that a negative information cascade may have been inhibited for obvious reasons: few people seek out opportunities to openly admit that they're either insufficiently smart or patient enough to finish reading a book.

Content cannot sell books when consumers have not yet engaged with it. Expectancy value sells books, and content may increase this, once experienced value feeds back into expectancy value. Yet, expectancy value, as we've seen, often has very little to do with content: it may derive from the way you think a purchase will make you feel or make someone else feel. Again, this is not to argue that content is unimportant. But creativity and ambition are held hostage if we think only of content. Content is just one part of a range of elements, systems, and dynamics. Although it may influence and determine many of these, directly and indirectly, projecting expectancy, it is not necessarily pre-eminent.

\section{How prismatic elements combine}

The easiest way to illustrate how expectancy value can be raised and lowered is to play around with subtraction and addition of elements. Taking again that example of Carlo Rovelli's Seven Brief Lessons in Physics, it is obvious to anyone who has come across the book that its aim is accessible distillation. It is short in length, its RRP was relatively low, and its format was initially a small hardback (small size suggests accessibility). Seven is a Goldilocks number in this context: it's a big enough number for the book to seem to have substance (Three Lessons in Physics might sound like we weren't getting much for our money) but small enough for it to sound easily manageable (how would it have sold if it had been called 14375 Lessons in Physics?). Earlier in this paper we considered how certain areas of utilitarian value may feel like locked doors, all but inaccessible. Sometimes the key that unlocks the door is through the introduction of a hedonic or self-identificatory aspect, as in Sophie's World and A Brief History of Time, respectively. Rovelli's book does everything possible to push the consumer through the door: everything conspires towards accessibility. If we remove 'Seven Brief' from the title, we lose something significant-a key element that has served to raise the book's expectancy value.

But what if we add 'Seven Brief' to another title to see the impact it has? Take cod, the fish. Seven Brief Lessons about Cod. It does not roll off the tongue or inspire a huge amount of curiosity. Are there really seven things I'd like to know about cod? How will I benefit from them being brief? It's possibly six more lessons than I need. Adding 'Seven Brief Lessons' to 'Cod' has zero impact. But if we add something else to 'Cod', might it work? How about Cod: A biography of the fish that changed the world? A biography? Of a fish? It sounds odd, treating a

\section{But if we add something else to 'Cod', might it work? How about Cod: $A$ \\ biography of the fish that changed the world? A biography? Of a fish?}

fish as worthy of such scrutiny, such personalization. Perhaps it warrants it. And if it genuinely changed the world, surely I should know about it? How did I not know that cod changed the world? I should probably read this book ... If turning something into a biography works here, can it work elsewhere? Physics: A biography? Not sure that works. But what about God: A biography?

This may all seem facetious, but there is a serious point about the mechanics in play. If prismatic elements worked in an additive way, then 'seven brief lessons in' and 'a biography' would have a fixed value that stayed predictably static and that one could simply add to other elements carrying a fixed value. But demonstrably that is not the case. Rather, prismatic elements work in a multiplicative way. Like lenses stacked against one another in a line, they successively broaden the beam of light which passes through. Unless, that is, the lenses are mismatched. Publishers often fail to realize this: they identify a book that is successful, ignore the fact that it is a construct of parts, ignore the universal ratio, and attempt to reuse the prismatic element that they believe has conferred success. Hence in the wake of The Little Book of Hygge some twenty books were soon published, 
all featuring 'hygge' in the title, all selling poorly. Similarly, thanks to the success of $A$ History of the World in 100 Objects, there were various follow-ons, very few of which sold well: A History of the World in Seven Cheap Things, A History of the World in 500 Walks, etc.

If prismatic elements do not have a fixed value, the only way to anticipate their product is our intuition. And their value will change over time. If you consider for a moment how authors can be seen as prismatic elements, it's easy to see why. Back in May 1927, Charles Lindbergh made the first solo flight across the Atlantic; 57 days later, after a period of frantic writing by Lindbergh, the book We was on shelves in America. It sold 650 ooo copies in its first year on sale. How many would it sell if its publication had been delayed until today? Or think of the cyclist Sir Bradley Wiggins. In 2008, he released a memoir, In Pursuit of Glory, which sold 11000 in hardback. Four years later he produced another, which sold 246000 in hardback. He was the same author, the same human being. However, he had won the Tour de France, the first Briton in 109 years to do so. As a prismatic element, he himself had evolved-his narrative had become more powerful as a way to reflect the motivation for achieving success (which is the core motivation reflected by nearly all sports memoirs, since readers seek to learn from and identify with the author's success). But what if that book had inexplicably had its publication delayed until today? What might it sell then? Among the constellation of elements that make up books, nothing is static.

\section{How prisms and motivations combine}

As we see, the best way to explore the relationship between prisms and motivations is by playing around with adding, subtracting, and switching elements to see what the impact is. Prisms, like motivations, are not static, but the easiest way to see how the two combine is to look at a prism or motivation that is comparatively static. At the risk of it becoming a leitmotif of the whole paper, 'Brexit' as a prismatic element provides a good case study. Figure 6 is a shot of a bookshop's selection of books on Brexit. Here, 'Brexit' is a common prismatic element across the titles. The question is how well this prismatic element concords with the other prismatic elements on offer as well as the range of motivations attached to the books. The sales are as follows:

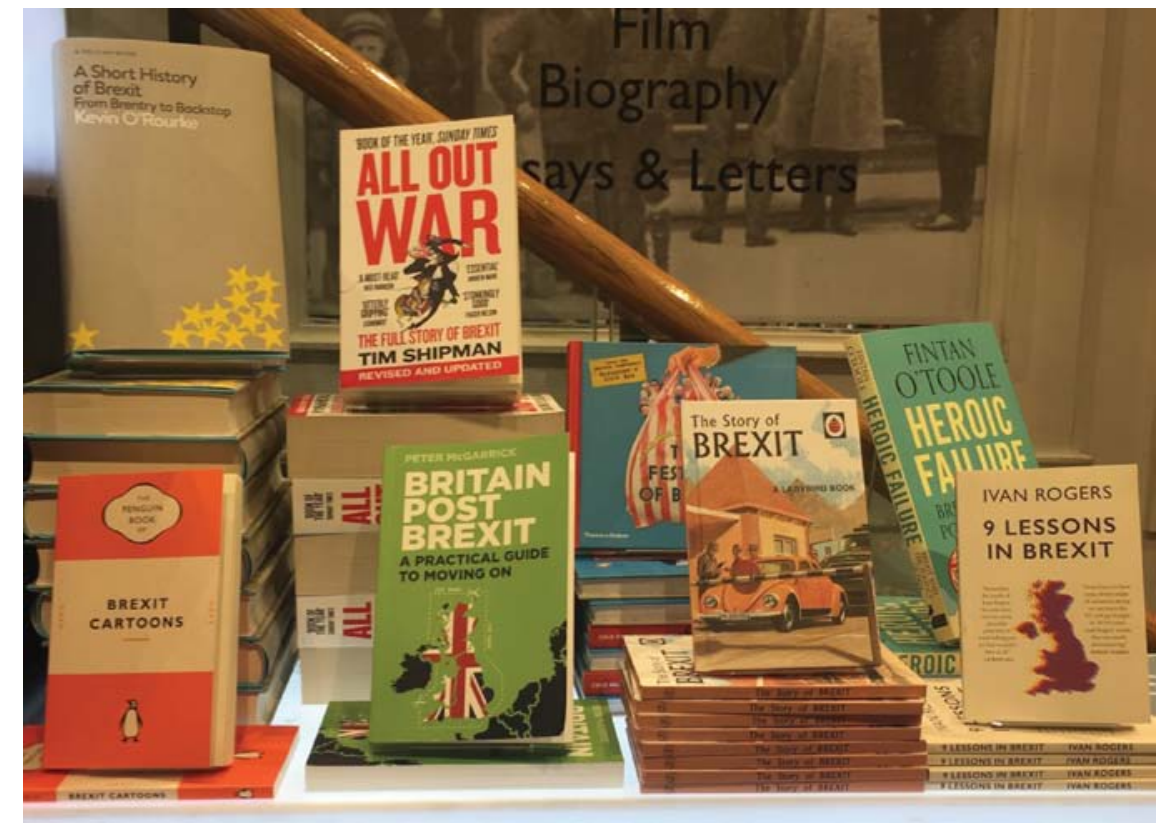

Figure 6. A display of Brexit-themed books. 


\begin{tabular}{|c|c|c|}
\hline The Ladybird Story of Brexit & 2018 & 124 ooo hardback \\
\hline The Penguin Book of Brexit & 2018 & 38 ooo paperback \\
\hline \multicolumn{3}{|l|}{ Cartoons } \\
\hline All out War: The full story of & 2017 & 35 ooo paperback \\
\hline \multicolumn{3}{|l|}{ how Brexit sank Britain's } \\
\hline \multicolumn{3}{|l|}{ political class } \\
\hline Heroic Failure: Brexit and the & 2018 & 14 ooo paperback \\
\hline \multicolumn{3}{|l|}{ politics of pain } \\
\hline 9 Lessons in Brexit & 2019 & 7000 paperback \\
\hline A Short History of Brexit & 2019 & 5 ooo hardback \\
\hline Cold War Steve Presents ... The & 2019 & 4000 hardback \\
\hline \multicolumn{3}{|l|}{ Festival of Brexit } \\
\hline Britain Post Brexit & 2018 & $15^{2}$ paperback \\
\hline
\end{tabular}

It is immediately clear that 'Brexit' works best when it is combined with the motivation to find humour or to give a humour gift to another person. In times of absurdity, we often seek humour - and Brexit represents extreme absurdity for many people in the UK. Brexit combined with the motivation to learn about recent history is weak-as evinced by A Short History of Brexit. It may be that this title will sell well in a future edition, but it is hard to sell the history of something that is not yet fully historical and is still in flux. What utilitarian value does this book have if it risks being immediately out of date and less current than a newspaper? The weakest motivation on display here is found with Britain post Brexit. The book is entirely speculative. Hence it again risks being rapidly out of date, and incorrect, and thus having little utilitarian value. On the more hedonic end of the spectrum, All out War, the earliest of these books to be published, offers the same sort of voyeuristic insider account as Fire and Fury: Inside the Trump White House or even The Mirrors of Downing Street; the latter, one of the bestselling books of 1921, contained a series of shockingly candid portraits of the principal political figures involved in the First World War. All out War is populated with stories and characters, portraying bewildering incompetence on a gigantic scale; as one online review puts it, 'if this doesn't put you off politicians for life, nothing will'. As with Fire and Fury, part of the hedonic pay-off and motivation is the desire to feel a sense of righteous indignation and outrage. The cartoon on the cover is another important prismatic element-it suggests hedonic. Compare the package of this book with Ivan Roger's 9 Lessons in Brexit and Fintan O'Toole's
Heroic Failure. The latter feel worthy, heavy-going, and exclusively utilitarian. Again we come up against the question of how much utilitarian value can be derived from something that is still an ongoing process. All of these titles can sensibly be grouped together as books on Brexit, yet the motivational value they offer the reader varies greatly, as do their sales.

In these examples, we have looked at Brexit as a prismatic element. It seems to have had a certain power-in combination with other elements and motivations - to drive sales. But earlier I also suggested that books like Hinch Yourself Happy might have, at a latent yet crucial level, something to do with Brexit; that certain books have achieved enormous sales by reacting in some way to Brexit without any reference to it in their title. Why? How can it be that the biggest-selling book to benefit from Brexit may not even mention it in its title?

\section{The secret force of subtlety}

If we look at books like The Hidden Life of Trees and The Little Book of Hygge, and the millions of colouring-in books that were sold globally during the height of their popularity, and if we say that their sales benefited from the fact they satisfied a depleted need for calm - then why should they sell so much better than a book with a title like Your Chronic Stress Problem and How You Must Deal with It? And if we say that a book like Middleton's First Man In benefited from the fact that it said something reassuring to an audience of young men who felt confused about 21st-century masculinity, then why should a book like that sell, but not a book with a title like Feel and Act like a Man in the Modern Age? If there was a book with a title like Buy This Book Now and You'll Feel Cleverer and More Connected with Other People, would it sell?

Few people like being told what to do. Or to wear, think, say, feel. It's the same when it comes to books. It's also true of advertising and marketing more generally. It's the reason why subtlety is key to successful publishing and perhaps also why publishing is so hard.

Yet there is a simple key to unlock this apparent secret. It comes down to one thing: the perceived locus of causation. This sits at the heart of all motivations and determines whether they are felt as intrinsic or extrinsic. Every single motivation can be influenced by this factor-whether we feel it originates within us or is imposed from outside. There is a spectrum. At one end, you 
can imagine extreme external regulation-being told exactly what to do. Move a little away from that and we enter the realm of introjected motivations - the voice in our head that tells us what we should and must do. A bit further and the individual begins to identify with the expressed motivation - for instance, you might understand and feel empathy for your manager's motivations and identify with them. A bit further still and those motivations may become integrated with our own, meaning they will increasingly be felt as intrinsic. In the course of this journey the perceived locus of causation shifts inwards. The reason this is so important to understand is that whereas extrinsic motivations make us feel less autonomous, less competent, and less connected, intrinsic motivations do the opposite (see Deci and Ryan, 2016).

\section{whereas extrinsic motivations make us}

feel less autonomous, less competent, and less connected, intrinsic motivations do the opposite

It follows that intrinsic motivation will be far more powerful than extrinsic motivation in driving sales. That doesn't mean that extrinsic motivations do not impact on us or the market. Consider how the external pressure to look slim and beautiful may be particularly powerful for someone who is in thrall to social media; this extrinsic motivation, to lose weight, may end up creating a deficit of self-esteem. As we've seen, deficit needs are immensely powerful: until they are satisfied we are subject to their persistent influence. But now consider how a book that implicitly promises weight loss while overtly signalling health benefits might appeal to a consumer. We can say to ourselves, perhaps truthfully, that we care for our own health first and foremost, that we are buying the book because we want to stave off diabetes, and therefore feel that a laudable intrinsic motivation is behind our purchase. The weight loss, we tell ourselves, is just a happy by-product.

Earlier, we touched on how in the wake of \#MeToo there was evidence of a male readership seeking answers to how they should behave, to what 21st-century masculinity should look like, and to how an era of uncertainty and stress demands solutions that supply confidence and certainty. Middleton's First Man In represents an unobvious, appealing, and aspirational solution to these questions. His book offers a vehicle for positive rather than negative self-identification. It allows us to step away from introjection and external pressure, moving instead towards a sense of autonomy, relatedness, and vicariously experienced competence. This axial approach can also be used to help understand and explain seemingly inexplicable, subtle movements in the market. For instance, if climate change is one of the greatest causes of anxiety, the most powerful solution will lie not in books that reflect the sense of despair back to us, but rather in opportunities for positive self-identification, high utilitarian value, and scope for autonomy and competence. To illustrate this progression from extrinsic to intrinsic, we can pick a few examples that sit at varying locations along it (Figure 7).

Taking these examples in turn, one can offer an analysis of why they sit where they do along the axis: The Decade We Could Have Stopped Climate Change (ostensibly
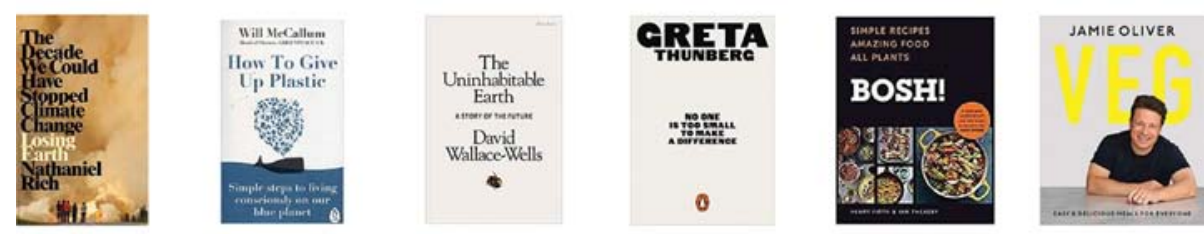

Figure 7. A selection of books that reflect, in more or less obvious ways, an engagement with anxiety over climate change. 
devoid of utilitarian value and carrying negative hedonic value-how depressing and unhelpful to be reminded of what we could have done but now can't!); How to Give up Plastic (presenting a sense of external regulation and limited utilitarian value-it's fairly obvious how to use less plastic); The Uninhabitable Earth (positive utilitarian value and self-identificatory value, since this has been posited successfully as a definitive book to read on climate change, but full of despair); Greta Thunberg's No One Is Too Small (offering an opportunity for positive self-identification-not unlike Michelle Obama's memoir, Becoming; Greta has become an ambassador for a positive response to climate change, so buying the book makes the statement, 'I'm with her;' the title alone offers a sentiment that many people would pay money to believe in and identify with); Veganism - as a group of titles this includes Jamie Oliver's phenomenally high-selling Veg, two books by Bosh!, and a slew of vegan cookery titles (offering a sense of positive self-identification, and hedonic value in the enjoyment of food, but, critically, they also confer a sense of competence, autonomy, and relatedness - by switching to a plant-based diet one feels as though one is actively behaving in a way that counteracts the extrinsic pressure and anxiety around climate change, joining a movement, gaining skills, acting in a free and positive, intrinsically motivated way; rather as colouring-in books offer a way to actively respond to general stress, cooking vegan food is an active response to climate change anxiety). Now we have picked apart the ways these titles work, it's unsurprising to see how they have sold:

$\begin{array}{ll}\begin{array}{l}\text { The Decade We Could Have } \\ \text { Stopped Climate Change }\end{array} & 4000 \text { hardback } \\ \text { How to Give up Plastic } & 8000 \text { hardback } \\ \text { The Uninhabitable Earth } & 19 \text { ooo hardback, } \\ & 54000 \text { paperback so far } \\ \text { No One Is Too Small to Make a } & 253 \text { ooo paperback } \\ \text { Difference } & \\ \text { Vegan/plant-based/vegetarian } & 1 \text { million+ } \\ \text { titles }\end{array}$

One cannot safely attribute gigantic sales to just one factor-Jamie Oliver's Veg and the Bosh! titles have sold for other reasons besides climate anxiety-but when one sees sizeable increases and patterns like this the interpretation above grows persuasive.

Whether we are seeking to understand why a book about trees might help people feel calmer or a book about the Holocaust might make a reader feel more optimistic about their political environment, the behavioural pattern outlined above offers answers. Our love for subtlety, as expressed in the book market, stems from a fundamental characteristic of human psychology: we desire to feel agency, to solve the puzzle and riddle ourselves, to experience the novelty of the world through our own eyes. We seek what is counter, original, spare, and strange. In providing the examples above, real and hypothetical, my purpose is to show that the selection, interpretation, and manipulation of prismatic elements, though typically things we're unconscious of, are fundamentally linked to the expected and experienced capacity of a given book to satisfy a motivational need. Consumers don't pause and start analysing these components when they are browsing in bookshops, but all of us are unconsciously making decisions and interpretations in ways that emerge from these unseen dynamics. We may reject a book because it feels patronizing or gravitate towards another book because we think the author is appealing, but these are ripples on the surface of a deeper sea. Books are not just collections of words. They offer

\section{We may reject a book because it feels patronizing or gravitate towards another book because we think the author is appealing, but these are ripples on the surface of a deeper sea.}

antidotes and salves to life's tribulations; when we feel out of control we look for control, when we are stressed we look for calm, when we feel lonely we seek connection, when we despair of the future we look for hope, when absurdity surrounds us we search for humour, and when we feel lost in uncertainty we hunger for certainty. But we seek what is new, surprising, fresh, and original, not what is obvious; we want to be drawn towards an 
experience through our intrinsic motivations. Amidst an epidemic of loneliness, we won't buy a book on how to deal with loneliness; we'll buy books inviting us to connect with something bigger than ourselves, with people whose lives matter to us, with whom establishing a connection somehow elevates, even ennobles, us.

\section{Conclusion}

Publishers in any market can, should they want to, take the approach modelled above, simply by diving deep into sales data and asking the same types of questions about the correlation between sales and history. They will then not only understand and potentially harness the power of contexts and cycles to their benefit, but also make more critically engaged decisions about not just what they publish, but how they publish it. In trying to distil the core conclusions of this paper, I have arrived at five:

- Books sell on the basis of their expectancy value rather than their experienced value (although the latter feeds into the former).

- Books sell on the basis not of one individual element, such as their content or author, but of the how various elements of the overall composite interact with each other and with the primary motivations that are reflected. These elements work in a way that is multiplicative rather than additive.

- There is a universal ratio that dictates that any book or composite that is repeated-in its effect upon the consumer-will be reduced by between a third and a half in its appeal and sales with each successive repetition.

- This universal ratio, in combination with a market's response to the sensation of novelty, explains why cycles exist in book markets.

- Motivations wax and wane, influenced by context, in a way that is historically intelligible and, to some degree, predictable.

Ultimately, there remain intangible elements that lie beyond the scope of this paper-'known unknowns' and 'unknown unknowns' that might influence a book's prospects. Whatever terms one uses, luck and intuition have played central roles in the publishing industry in the past, just as they do in the present and will do in future. There are many other avenues and areas this paper has had to avoid for the sake of concision and clarity. I hope that it will prompt further research and collaboration.

\section{References}

Belk, R. W., 1988. 'Possessions and the Extended Self', Journal of Consumer Research, 15 (2), pp. 139-168.

Belk, R. W., 2013. 'Extended Self in a Digital World', Journal of Consumer Research, 40 (3), pp. 477-500.

Bhaskar, M., 2013. The Content Machine: Towards a theory of publishing from the printing press to the digital network (London: Anthem Press).

Deci, E. L. and Ryan, R. M., 2016. Self-Determination Theory:Basic psychological needs in motivation, development, and wellness (New York: Guilford Press).

James, W., 189o. The Principles of Psychology (New York: Henry Holt).

Maslow, A., 1943. 'A Theory of Human Motivation', Psychological Review, 50 (4), pp. 370-396.

Moretti, F., 1994. 'Modern European Literature: A geographical sketch', New Left Review, 206.

Ogilvy, D., 1983. Ogilvy on Advertising (New York: Vintage Books).

Sassoon, D., 2006. The Culture of the Europeans: From 1800 to the present (London: HarperPress).

Will, G. F., 2018. 'We Have an Epidemic of Loneliness. How can we fix it?', Washington Post, 12 October. 